\title{
Intensive Vegetable Production Degrades Volcanic Ash Soil in Cabintan, Ormoc City, Philippines
}

\author{
Frances Mae Pizon ${ }^{1 *}$ and Anabella B. Tulin ${ }^{2}$
}

\section{ABSTRACT}

Long-term intensive cultivation leads to soil-related problems. This study was conducted to know the changes in physico-chemical properties of volcanic ash soil (Andisol) in Barangay Cabintan, Ormoc City, Leyte after ten years of intensive vegetable production. Five sampling sites were selected, representing fallow and intensively cultivated areas. The soils were collected and analyzed for particle size analysis (PSA), bulk density (Db), soil pH, organic matter (OM), nitrogen (N), available phosphorus $(\mathrm{P})$ and exchangeable bases potassium $(\mathrm{K})$, magnesium $(\mathrm{Mg})$, calcium $(\mathrm{Ca})$, and sodium $(\mathrm{Na})$. The findings of the current study were compared to the results reported by the ACIAR project ten years ago.

The results revealed that the soil physico-chemical properties of Andisol changed within ten years. There were significant differences in soil physicochemical properties of Andisol across sites and depths as influenced by the two types of soil management over ten years. Soil management practices influenced the nutrient supplying capacity and the physico-chemical properties of the soil. Soil texture did not vary except for sites $\mathrm{C}$ and $\mathrm{E}$ (intensively cultivated areas). The bulk density remained low while the soil $\mathrm{pH}$, soil organic matter, nitrogen, and exchangeable bases decreased. However, the available phosphorus increased under intensive vegetable production. The overall results highlighted the need to employ the appropriate soil management, specifically fertilizer application. An accurate and exact combination of organic and inorganic fertilizers is highly recommended in the area to obtain the desired vegetable yield.

Keywords: Andisol, intensive cultivation, physico-chemical properties

\section{INTRODUCTION}

The rapid increase of the world's population has led to the increase in the demand for food. Despite this population increase, prime agricultural lands are being converted into residential areas, malls, and factories. These circumstances have led farmers to cultivate their lands intensively to meet the demand for food. Cabintan, Ormoc City, Leyte, is one of the areas where vegetables are intensively

\footnotetext{
${ }^{1}$ Department of Soil Science, Visayas State University, Visca, Baybay City, Leyte, Philippines

${ }^{2}$ Office of the Graduate School, Visayas State University, Visca, Baybay City, Leyte, Philippines 
produced (Tulin et al 2013). Cabintan soils are volcanic soils (Navarrete et al 2008; Magahud \& Asio 2009; Tulin et al 2013, Nierves \& Salas 2015; Kangleon \& Salas 2017), which resulted from the extensive volcanic activities during Tertiary and Quaternary geologic time scale period (Otsuka et al 1988; Jahn \& Asio 1998; Navarrete et al 2008).

Andisols or volcanic soils exhibit andic properties, distinctive properties which include high water-holding capacity and the ability to "fix" large quantities of phosphorus (Ping, 2000). It is also high in organic matter (OM) content, which can be as high as 12\% (Diez et. al., 2006), making its nitrogen $(\mathrm{N})$ and water retention relatively high. These and other factors make Andisols generally well suited for various land use, such as agricultural production. In spite of its generally favorable properties, Andisols pose some fertility challenges. This soil has low bulk density, resulting in low weight-bearing capacity. Despite the high $\mathrm{P}$ content, available $\mathrm{P}$ is being lack up in these soils due to their large content of minerals that strongly absorb P (e.g. Al/Fe oxyhydroxides, allophane) (Guadalix \& Pardo 1994; Johnson \& Loeppert 2006; Redel et al 2008) making it unfavorable for plant to take up. Acid Andisols have high $\mathrm{P}$ sorption rates due to irreversible chemisorption of $\mathrm{P}$ to amorphous minerals such as allophane, imogolite, and iron and aluminum hydroxides, precipitation as $\mathrm{Al}$ and Fe phosphates, and complexation with organometallic complexes (Wada \& Gunjigake 1979; Shoji et al 1993). Andisols react strongly with $P$ to form stable compounds of low solubility, often making this nutrient unavailable to plants. In addition, Andisol has a pH value of 4-5, meaning this type of soil is acidic. Most of the nutrients in this $\mathrm{pH}$ value are not available for the plants to take up. To solve this problem, researchers and farmers practice soil amelioration, such as fertilizer application.

However, unbalanced nutrient fertilizer application may be harmful in the long run, causing soils to be unproductive. Continuous high application of fertilizers, especially $\mathrm{P}$ - and $\mathrm{N}$-containing inorganic fertilizers for a long period of time, may cause leaching of these nutrients, thus contaminating groundwater and nearby surface waters, including lakes and rivers (Scheffer \& Schactschabel 1992; Logan 2000; Magahud \& Asio 2009). Therefore, correct identification and proper management of soil fertility problems are necessary in boosting crop production and sustaining higher yields in an extended period.

Since intensive vegetable production in Barangay Cabintan, Ormoc City, Leyte has been continuously practiced over a long period, an in-depth analysis of its physico-chemical properties should be done. Thus, this study was conducted to determine the changes in physico-chemical properties of Andisol ten years after initial analysis and assess the impact of intensive vegetable production on the nutrient supplying capacity of volcanic ash soil at $0-20 \mathrm{~cm}$ and $20-40 \mathrm{~cm}$ depth. The results are very valuable in predicting the fate of the nutrient supplying capacity of the soil through time. Understanding this serves as a basis or reference for better soil management in the future. 


\section{MATERIALS AND METHODS}

\section{Site Selection}

This study was conducted in the central highlands of Leyte, specifically in Cabintan, Ormoc City, Leyte. This has an elevation of approximately 700 meters above sea level (masl) (Fig. 1). This location is classified as Af by Köppen and Geiger (Climate 2020). The temperature here averages $26.9^{\circ} \mathrm{C} \mid 80.4^{\circ} \mathrm{F}$ while the rainfall is around $2456 \mathrm{~mm}$ | 96.7 inch per year (Climate, 2020).

The selection of the study site was based on the ACIAR project conducted here from 2008 to 2012 (10 years before) (Tulin 2019). This study was done to compare the changes in soil physico-chemical properties of Andisol after ten years of intensive vegetable production. Five sites were selected in Cabintan, Ormoc City, Leyte with the same plain topography. Three sites (A, C, and $E$ ) were intensively cultivated (continuous) for vegetable production for about 10 years. Site B was abandoned for about eight years after intensive cultivation and was being developed for ornamental production at the time of the study. Site D was used as a grazing area for about five (5) years after intensive cultivation. Sites B and D were both classified as fallow areas. Therefore, only two soil management practices were highlighted in this study (intensively cultivated area and fallow area) (Fig. 2).

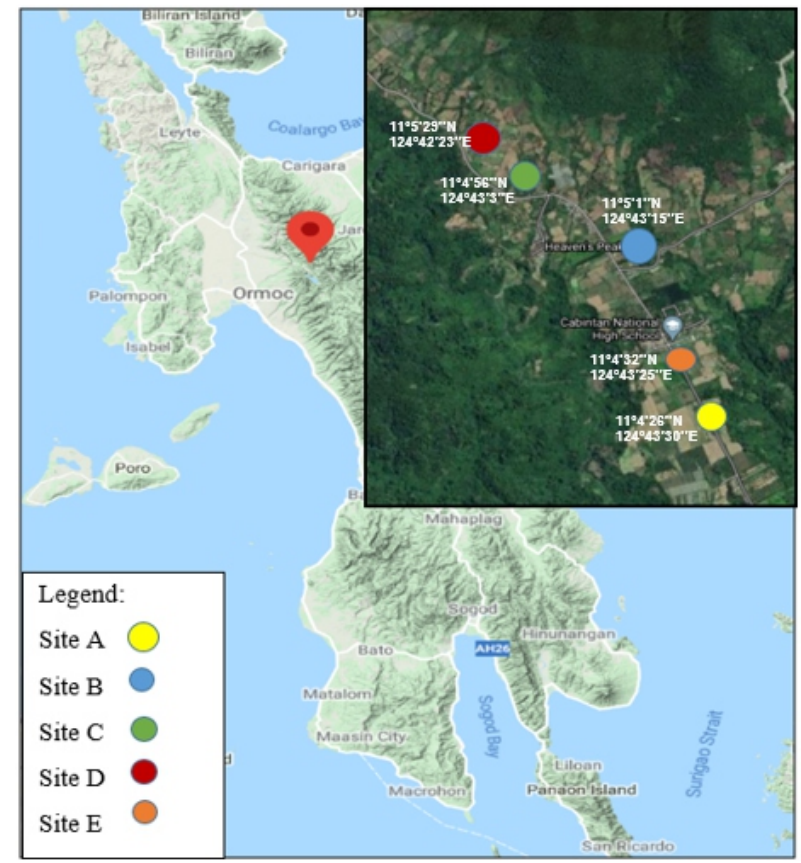

Legend:

Site $A$ - intensive vegetable production Site D - fallow land

Site $B$ - fallow land

Site $\mathrm{E}$ - intensive vegetable production

Site $\mathrm{C}$ - intensive vegetable production

Figure 1. Map showing the sampling sites in Barangay Cabintan, Ormoc City, Leyte 

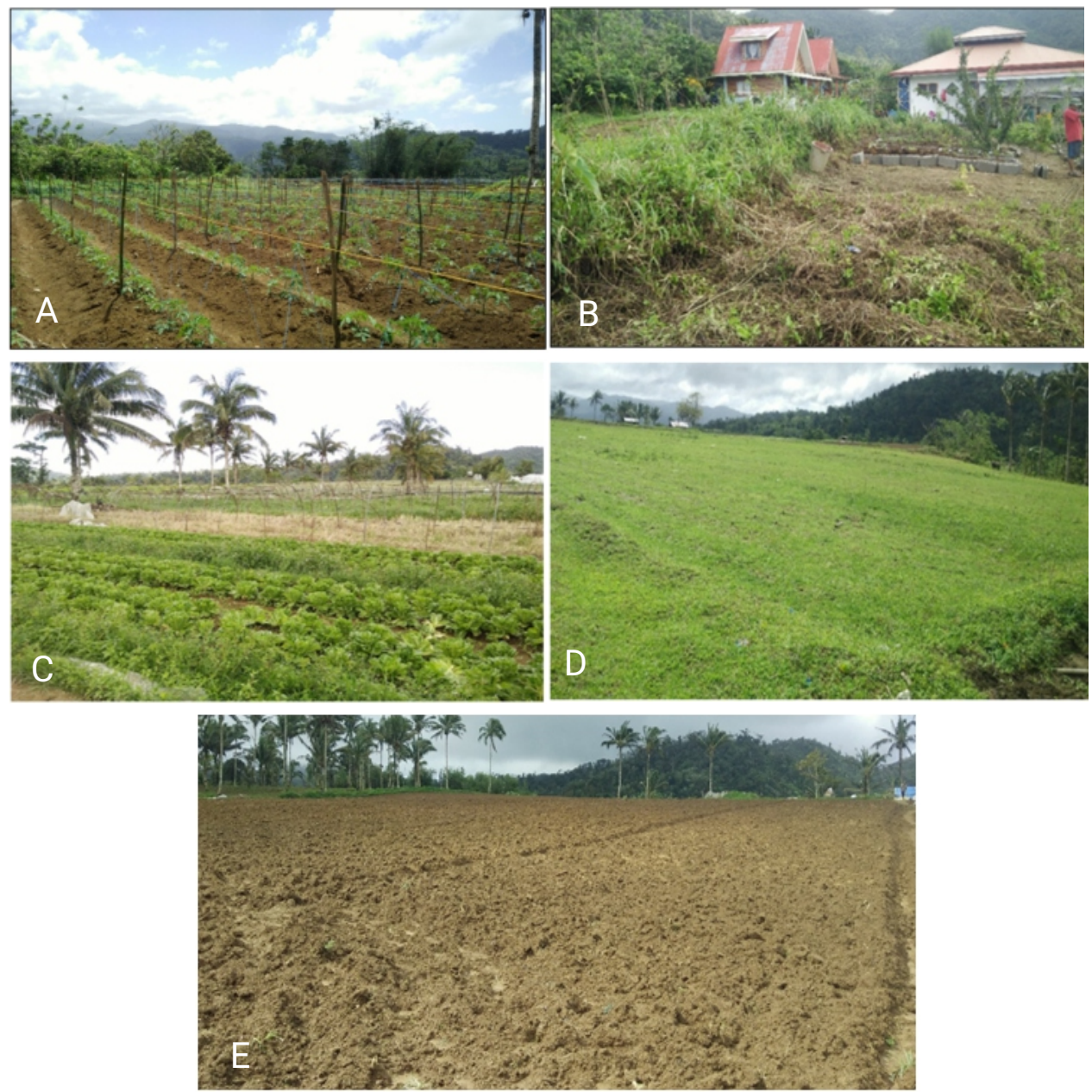

Figure 2. Site A, owned by Emilardo Quimpano (intensively cultivated), Site B, owned by Ramil Morales (abandoned land/fallow land), Site C, owned by Alvin Morales (intensively cultivated), Site D, owned by Dionisio Malabago (grazing area/fallow land), Site E, owned by Victorino Avila (intensively cultivated)

\section{Soil Sample Collection, Preparation, and Analysis}

The soil samples were randomly collected in each site at $0-20 \mathrm{~cm}$ and $20-40 \mathrm{~cm}$ using a soil auger. There were three (3) replications in each depth at each sampling plot. For each replication, a quadrant measuring $5 \mathrm{~m} \times 5 \mathrm{~m}$ was constructed. Inside the quadrant, about five (5) subsamples were collected and composited. There were six (6) composite samples in each sampling plot, three (3) for 0-20 cm and three (3) for $20-40 \mathrm{~cm}$. These composite soil samples were placed in labeled plastic bags and were brought to the laboratory for processing and analysis. 
All soil samples were passed through a $10 \mathrm{~mm}$ sieve to remove leaves and rock fragments, air-dried, pulverized, and sieved again using a 2-mm wire mesh to get the coarse fraction needed to determine most soil physical and chemical properties. Enough samples were further pulverized and sieved through a $0.425-\mathrm{mm}$ wire mesh for $\mathrm{OM}$ and total $\mathrm{N}$ determination (\%). The prepared soil samples were analyzed for the following parameters listed below. The calculation of all soil parameters was based on the oven-dry weight of the soil.

\section{Soil Physical Analysis}

The bulk density was determined using the core method ISRIC (2002). Moisture Content at Field Capacity $\left(\mathrm{MC}_{\mathrm{FC}}\right)$ was done by measuring the fresh weight and ovendry weight of the soil. Particle size analysis was determined using the pipette method (ISRIC 1995).

\section{Soil Chemical Analysis}

Soil $\mathrm{pH}$ determination was done following the potentiometric method using a 1:2.5 soil-water ratio (ISRIC 1995). While soil OM was analyzed using the modified Walkey-Black method (Nelson \& Sommers 1982). Total N was determined following the Kjeldahl method (USDA 2004). Available P was analyzed using the Bray P-2 extraction method (Jackson 1958) by Murphy and Riley (1962) for color development. Exchangeable Bases ( $\mathrm{K}, \mathrm{Ca}, \mathrm{Na}$, and $\mathrm{Mg}$ ) were extracted using one (1) $\mathrm{N} \mathrm{NH}_{4} \mathrm{OAc}(\mathrm{pH}$ 7.0) method (ISRIC 1995) and quantified through an Atomic Absorption Spectrophotometer (Varian 220 FS).

\section{Data Analyses and Interpretation}

All data gathered was analyzed using Statistical Tool for Agricultural Research (STAR) based on $2 \times 5$ factorial arranged in Randomized Complete Block Design (RCBD) with three replications. Each parameter was tested for difference of previous and current results using analysis of variance (ANOVA), and comparison of means (between intensively cultivated and fallowed land) was tested using Tukey's Honest Significant Difference (HSD) test at a $5 \%$ level of significance. The value determined for each property was compared with the criteria developed by Landon (1991) to determine if they indicate low, moderate, or high levels.

\section{RESULTS AND DISCUSSION}

\section{General Observation}

Soil is the principal resource for land cultivation. As mentioned by Hillel (1992) it is the foundation of all civilizations and serves as a major link between biogeochemical systems and climate (Yaalon 2000). Young and Crawford (2004) added that the soil supports biodiversity and plays a major role in the ability of ecosystems to provide diverse services necessary for human well-being. Therefore, soils must not be taken lightly in any development attempt either in the local, regional, or global level. 
Converting natural land to intensively managed agriculture land in the long term can affect the soil quality because the soil's structure is disturbed and soil organic matter is lost. These impacts damage the fertility status of the soils and ecosystem services provided by the soils. The current study showed the changes in physicochemical properties of volcanic ash soil after ten years of intensive vegetable production in Cabintan, Ormoc City, Leyte. Three sites were intensively cultivated continuously for the past 10 years while the two sites were abandoned or fallowed for 5-8 years. The study highlighted that most of the soil physico-chemical properties of volcanic ash soil or Andisol in Barangay Cabintan, Ormoc City, Leyte changed after ten years depending on the soil management applied.

\section{Soil Texture}

In this study, most of the soil texture in Cabintan, Ormoc City, Leyte were classified as sandy loam and sandy clay loam, which is a typical feature of an Andisol (Shoji et al 1993) (Fig. 3). The coarser fraction of Andisol was often dominated by volcanic glass (McDaniel et al 2012). Most of the soil texture was not affected by the soil management and time except sites $C$ and $E$ (intensively cultivated), from silty clay and clay loam to sandy loam and sandy clay loam. It could be due to the management practices applied by the farmer (organic matter occluded in the aggregate) or due to the active weathering process, which could have contributed to a high composition of bigger soil particles. In areas where excessive leaching and heavy rainfall occurred, most of the soil were coarse specifically in tropical areas. This is because fine materials are being leached leaving the particles that are coarse. As claimed by lgwe et al (1995) most of the soils they studied were sandy loam to sandy clay in the subsoil. Jaiyeoba (2003) supported this idea where in the soil surface, coarse particle was superior in various cultivated area and then increased over time when weathering processes continues.

Legend:

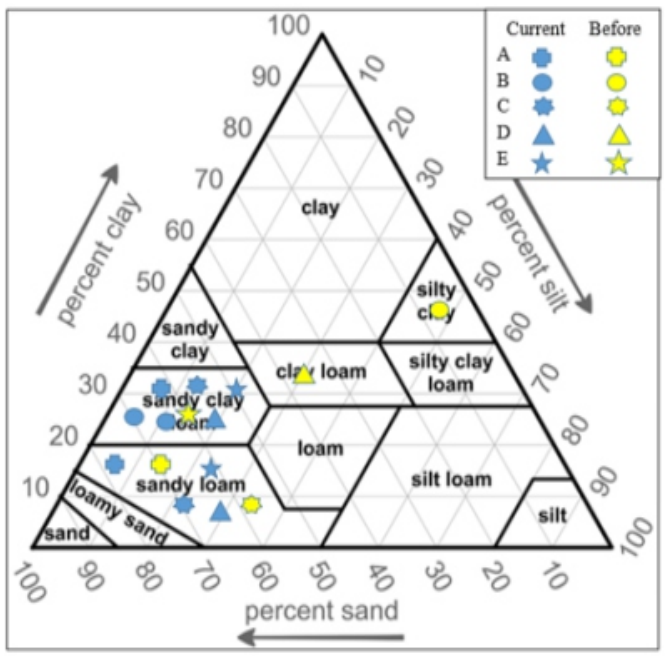

Site A - intensive vegetable production

Site $B$ - fallow land

Site $\mathrm{C}$ - intensive vegetable production
Site D - fallow land

Site $\mathrm{E}$ - intensive vegetable production

Figure 3. Textural classification of Andisol in Barangay Cabintan, Ormoc City, Leyte 


\section{Bulk Density}

Generally, the bulk density of Andisol is low, and this is due to the volcanic materials or minerals unique to Andisol. In this study, bulk density was not affected by the type of soil management with time. Figure 4 shows that in all sites at $0-20 \mathrm{~cm}$, bulk density remained low over time in all types of soil management. Furthermore Figure 4 shows that there was no significant difference between sites or soil management. All bulk density values ranging from 0.42 to $0.91 \mathrm{~g} / \mathrm{cm}^{3}$ (Table 1) are classified into recently cultivated land (Landon 1991). This means that the bulk density obtained in all sites and depths were low. This situation could be attributed to the presence of important non-crystalline minerals in soil, such as allophane, which results in high porosity (Shoji et al 1993). Moreover, allophanic Andisols that are rich in organic substance, such as humus, tend to be much lower in bulk density compared to low allophanic Andisol. Application of chicken dung manure and continuous cultivation was among the fertility management practices done by most of the vegetable growers in Cabintan. This practice could also result in improved soil bulk density values, making the soil favorable for plant growth.

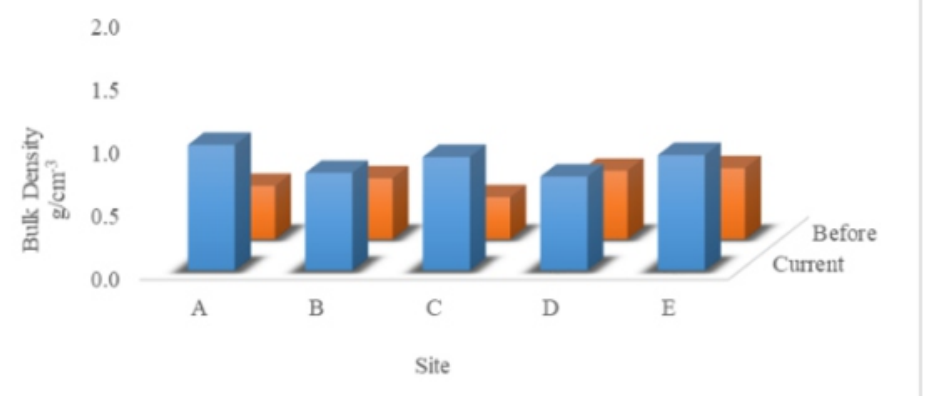

Figure 4. Comparison of bulk density $\left(\mathrm{g} / \mathrm{cm}^{-3}\right)$ between the current and previous studies at $0-20 \mathrm{~cm}$ as influenced by soil management

\section{Moisture Content at Field Capacity}

In this study, the soil moisture content obtained was closely related to the previous research (ACIAR Project)(Table 2), which ranged from $17.56 \%$ to $27.75 \%$. The percent moisture content at field capacity was dependent on the texture of the soil. The coarser the soil, the lower its moisture content, and the finer the soil, the higher its moisture content. Figure 5 shows the comparison of soil moisture content between the previous and the current study at $0-20 \mathrm{~cm}$ and $20-40 \mathrm{~cm}$. This shows that soil moisture content was not significantly affected by soil management, unless the texture of the soil changes due to the soil management applied. Besides, the soil moisture content is high in soil used for crop production compared to forest and grassland due to the type of tillage involved (Gong 2016). Soil hold water (moisture) through their aggregation qualities and colloidal properties. The colloids and other particles of the soil and even the pores hold the water. Surface tension and surface attraction are the ones responsible for maintaining water in the soil after the drainage has stopped. 
Table 1. Data from the current study (March - June, 2020)

\begin{tabular}{|c|c|c|c|c|c|c|c|c|c|c|c|c|}
\hline SITE & $\begin{array}{l}\text { SOIL DEPTH } \\
(\mathrm{cm})\end{array}$ & $\begin{array}{c}\text { BULK } \\
\text { DENSITY } \\
\left(\mathrm{g} / \mathrm{cm}^{3}\right)\end{array}$ & SOIL pH & $\mathrm{OM}(\%)$ & $\mathrm{N}(\%)$ & $\begin{array}{c}\mathrm{P} \\
(\mathrm{mg} / \mathrm{kg})\end{array}$ & $\begin{array}{c}\mathrm{K} \\
(\mathrm{cmol} / \mathrm{kg})\end{array}$ & $\begin{array}{c}\mathrm{Ca} \\
(\mathrm{cmol} / \mathrm{kg})\end{array}$ & $\begin{array}{c}\mathrm{Mg} \\
(\mathrm{cmol} / \mathrm{kg})\end{array}$ & $\begin{array}{c}\mathrm{Na} \\
(\mathrm{cmol} / \mathrm{kg})\end{array}$ & $\mathrm{MC}(\%)$ & SOIL TEXTURE \\
\hline \multirow[t]{2}{*}{$A$} & $0-20$ & 0.99 & $4.980 \mathrm{c}$ & $4.938 b$ & $0.247 b$ & $24.96 \mathrm{a}$ & $0.122 \mathrm{a}$ & 0.212 & $0.288 \mathrm{a}$ & 0.006 & 18.220 & sandy loam \\
\hline & $20-40$ & 0.90 & $4.757 \mathrm{c}$ & $4.386 \mathrm{~b}$ & $0.219 b$ & $6.95 \mathrm{a}$ & $0.127 \mathrm{a}$ & 0.052 & $0.125 b$ & 0.013 & 19.650 & sandy loam \\
\hline \multirow[t]{2}{*}{ B } & $0-20$ & 0.77 & $5.303 \mathrm{a}$ & $5.027 \mathrm{a}$ & $0.251 \mathrm{a}$ & $10.15 \mathrm{c}$ & $0.055 b$ & 0.090 & $0.054 \mathrm{c}$ & 0.008 & 17.560 & sandy loam \\
\hline & $20-40$ & 0.64 & $5.223 \mathrm{a}$ & $4.743 \mathrm{a}$ & $0.237 a$ & $4.98 \mathrm{ab}$ & $0.031 \mathrm{~b}$ & 0.018 & $0.035 \mathrm{~b}$ & 0.008 & 18.120 & sandy loam \\
\hline \multirow[t]{2}{*}{ C } & $0-20$ & 0.89 & $5.207 \mathrm{ab}$ & $4.204 b$ & $0.210 \mathrm{~b}$ & $3.20 \mathrm{~d}$ & $0.066 \mathrm{a}$ & 0.222 & $0.200 \mathrm{ab}$ & 0.015 & 27.750 & sandy loam \\
\hline & $20-40$ & 0.58 & $5.033 \mathrm{~b}$ & $5.362 \mathrm{~b}$ & $0.268 \mathrm{~b}$ & $0.45 b$ & $0.029 a$ & 0.477 & 0.407 a & 0.007 & 27.280 & sandy loam \\
\hline \multirow[t]{2}{*}{$\mathrm{D}$} & $0-20$ & 0.74 & $5.057 \mathrm{bc}$ & $4.981 \mathrm{a}$ & $0.249 a$ & $26.64 \mathrm{a}$ & $0.185 b$ & 0.052 & $0.087 \mathrm{bc}$ & 0.006 & 25.890 & sandy clay loam \\
\hline & $20-40$ & 0.75 & $5.030 \mathrm{~b}$ & $4.922 \mathrm{a}$ & $0.246 a$ & $7.86 \mathrm{a}$ & $0.070 \mathrm{~b}$ & 0.033 & 0.082 b & 0.005 & 26.540 & sandy clay loam \\
\hline \multirow[t]{2}{*}{$E$} & $0-20$ & 0.91 & $5.043 \mathrm{bc}$ & $4.588 b$ & $0.229 \mathrm{~b}$ & $15.80 \mathrm{~b}$ & $0.089 a$ & 0.073 & $0.163 \mathrm{abc}$ & 0.008 & 19.230 & sandy clay loam \\
\hline & $20-40$ & 0.85 & $5.273 \mathrm{a}$ & $4.396 b$ & $0.170 \mathrm{~b}$ & $2.79 a b$ & $0.166 \mathrm{a}$ & 0.177 & $0.401 \mathrm{a}$ & 0.009 & 18.670 & sandy clay loam \\
\hline
\end{tabular}

Table 2. Data from the previous study (ACIAR project) 2008-2012 (Tulin 2019)

\begin{tabular}{|c|c|c|c|c|c|c|c|c|c|c|c|c|}
\hline SITE & $\begin{array}{l}\text { SOIL DEPTH } \\
\quad(\mathrm{cm})\end{array}$ & $\begin{array}{c}\text { BULK } \\
\text { DENSITY } \\
\left(\mathrm{g} / \mathrm{cm}^{3}\right)\end{array}$ & SOIL pH & $\begin{array}{l}\text { OM } \\
(\%)\end{array}$ & $\mathrm{N}(\%)$ & $\begin{array}{c}P \\
(\mathrm{mg} / \mathrm{kg})\end{array}$ & $\begin{array}{c}\mathrm{K} \\
(\mathrm{cmol} / \mathrm{kg})\end{array}$ & $\begin{array}{c}\mathrm{Ca} \\
(\mathrm{cmol} / \mathrm{kg})\end{array}$ & $\begin{array}{c}\mathrm{Mg} \\
(\mathrm{cmol} / \mathrm{kg})\end{array}$ & $\begin{array}{c}\mathrm{Na} \\
(\mathrm{cmol} / \mathrm{kg})\end{array}$ & MC (\%) & SOIL TEXTURE \\
\hline \multirow[t]{2}{*}{ A } & $0-20$ & 0.42 & 5.50 & 6.315 & 0.454 & 0.101 & 0.272 & 0.965 & 0.194 & 0.038 & 19.43 & sandy loam \\
\hline & $20-40$ & & 5.58 & 3.239 & 0.259 & 0.126 & 0.132 & 0.843 & 0.137 & 0.149 & 18.78 & \\
\hline \multirow[t]{2}{*}{ B } & $0-20$ & 0.48 & 5.66 & 6.667 & 0.523 & 0.153 & 0.309 & 0.704 & 0.177 & 0.111 & 18.25 & sandy loam \\
\hline & $20-40$ & & 5.93 & 3.809 & 0.260 & 0.133 & 0.329 & 0.509 & 0.122 & 0.112 & 17.34 & \\
\hline \multirow[t]{2}{*}{ C } & $0-20$ & 0.33 & 5.65 & 5.561 & 0.372 & 0.175 & 0.188 & 0.726 & 0.087 & 0.040 & 38.67 & silty clay \\
\hline & $20-40$ & & 5.57 & 4.392 & 0.321 & 0.178 & 0.334 & 1.052 & 0.102 & 0.121 & 38.54 & \\
\hline \multirow[t]{2}{*}{$\mathrm{D}$} & $0-20$ & 0.54 & 5.13 & 5.146 & 0.400 & 0.152 & 0.645 & 0.620 & 0.122 & 0.178 & 26.28 & sandy clay loam \\
\hline & $20-40$ & & 5.54 & 3.289 & 0.289 & 0.192 & 0.425 & 0.902 & 0.188 & 0.108 & 25.77 & \\
\hline \multirow[t]{2}{*}{$E$} & $0-20$ & 0.56 & 5.39 & 4.398 & 0.377 & 0.179 & 0.411 & 0.909 & 0.184 & 0.101 & 37.65 & clay loam \\
\hline & $20-40$ & & 5.24 & 2.620 & 0.250 & 0.167 & 0.401 & 0.460 & 0.103 & 0.144 & 38.23 & \\
\hline
\end{tabular}


(a)

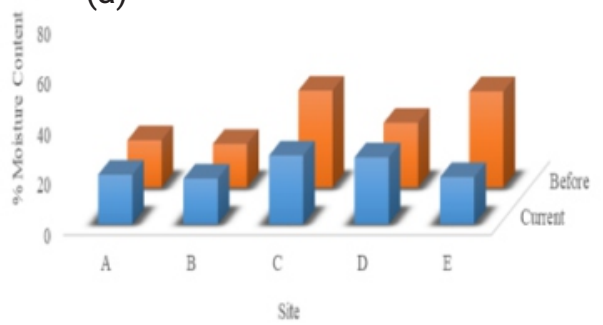

(b)

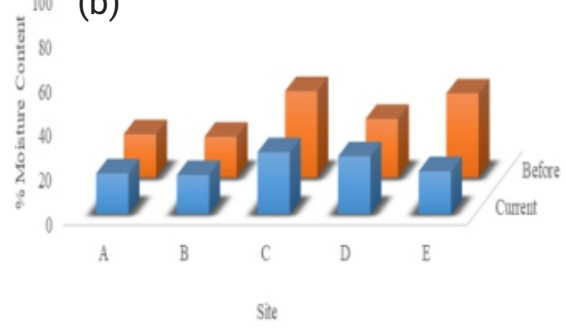

Figure 5. Comparison of soil moisture content (\%) between the current and previous studies at 0-20 (a) and 20-40 (b) cm depth as influenced by soil management

\section{SoilpH}

The results showed that soil pH at 0-20 and 20-40 cm depth decreased after ten years as influenced by intensive cultivation (Fig. 6). The pH values $\left(\mathrm{H}_{2} \mathrm{O}\right)$ ranged from 4.75 to 5.44 and were classified as strongly acidic to very strongly acidic, according to Landon (1991). A significant difference in soil pH was observed between the two types of soil management over ten years. Sites $A, C$, and $E$ (intensive cultivation) had significantly lower soil $\mathrm{pH}$ compared to that of sites $\mathrm{B}$ and D (fallowed land) (Fig. 7). This could be attributed to the inorganic fertilizer applied to the soil, especially nitrogen fertilizer. The same result was obtained in the study of Bahrami et al (2010), where the low pH values of the soils under tea cultivation were due to the intensive application of nitrogen fertilizer.

(a)

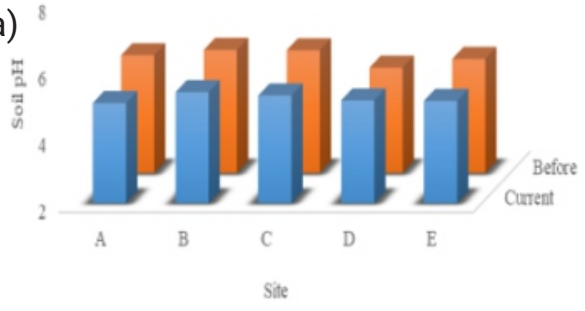

(b) 8

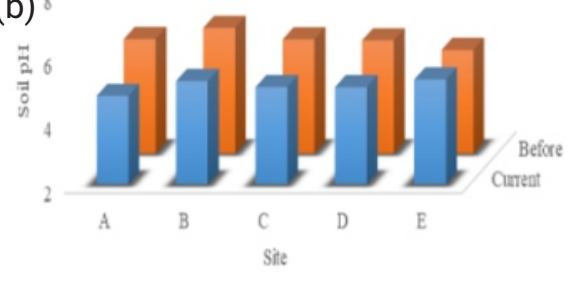

Figure 6. Comparison of soil $\mathrm{pH}$ between the current and previous studies at 0-20 (a) and 20-40 (b) cm depth as influenced by soil management

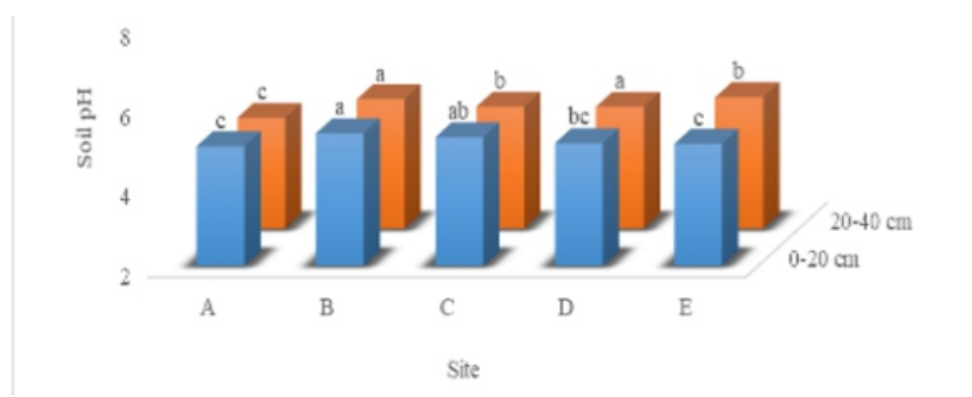

Figure 7. Comparison of soil pH between sites at $0-20$ and $20-40 \mathrm{~cm}$ as influenced by soil management 


\section{Soil Organic Matter}

The results revealed that soil organic matter was affected by soil management over a long period (10 years). A significant difference in soil organic matter was noticed between sites but not in depths (Fig. 8) Sites A, C, and E (intensive cultivation) showed significantly lower soil organic matter compared to sites $B$ and D (fallowed land) (Fig. 9). However, all the obtained soil organic matter values are classified as low, according to Landon (1991). The higher organic matter content in sites $B$ and $D$ was attributed to the vegetation on the soil, which was carabao grass. The fast accumulation of the grass residues contributed to the amount of soil organic matter present in the soil. The application of organic matter, either from animals or crop residues in the soil, also influenced soil organic matter content. This is similar to the study by Bahrami et al (2010) in which they found that agricultural activities, mainly the export of leaves, had caused lower soil organic matter. Nanganoa et al (2019) also found that there was less soil organic matter in cultivated areas than in forest areas. Therefore, accumulation of soil organic matter content is significant as this improves soil properties; hence, improving plant growth and soil health. Most soils in Cabintan have been subjected to intensive cultivation due to the limited availability of agricultural lands. These findings signify the importance of appropriate soil management in maintaining soil health or soil quality.

(a)

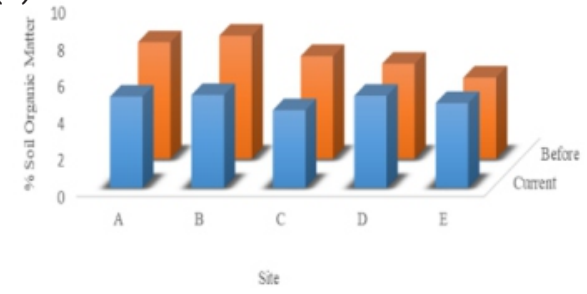

(b)

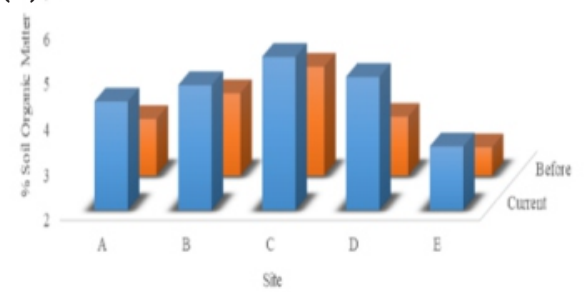

Figure 8. Comparison of soil organic matter (\%) between the current and previous studies at 0-20 (a) and 20-40 (b) cm depth as influenced by soil management

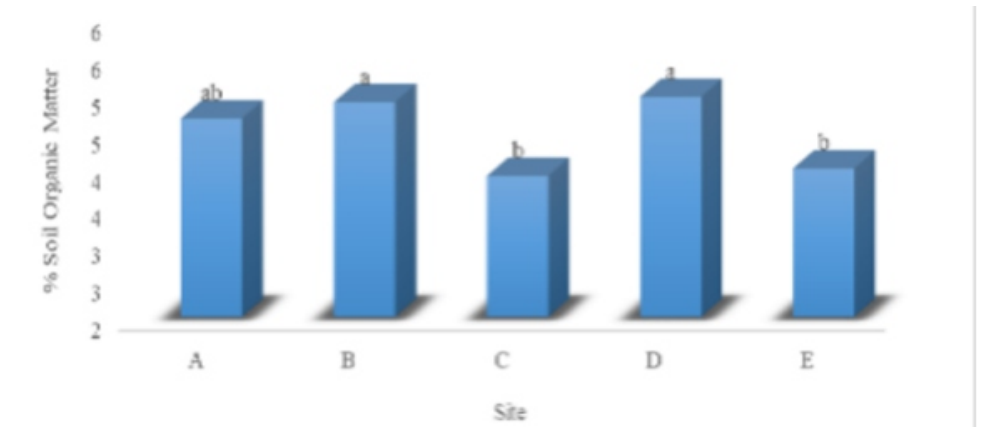

Figure 9. Comparison of soil organic matter (\%) between sites at $0-20 \mathrm{~cm}$ as influenced by soil management 


\section{Total Nitrogen}

Nitrogen occurs in various agricultural ecosystems because it can exist in several valence states within an ecosystem. The results revealed a similar trend in soil organic matter in terms of soil management over a long period. It is because nitrogen is bound in organic matter (Khrsat et al 2008). There was a significant difference in total nitrogen between each soil management but this did not vary in depths (Fig. 10). Sites A, C, and E (intensive cultivation) showed a significantly lower total nitrogen compared to sites $B$ and $D$ (fallowed land) (Fig. 11). The same result was obtained in the study of Rahman et al (2008), where the effect of long-term tillage practices on total $\mathrm{N}$ was similar to its effect on organic matter. This was attributed to the type of vegetation in the area and management practices. Jaiyeoba (2003) reported that, in both layers, there was a progressive loss of nitrogen over time. The higher organic matter also resulted in higher total nitrogen since nitrogen tends to bind with organic matter. However, all of the results obtained in total nitrogen were $>1$ and were classified as low (Landon 1991). Application of fertilizer $\mathrm{N}$ and organic matter is necessary for this type of soil to obtain maximum yield.

(a)

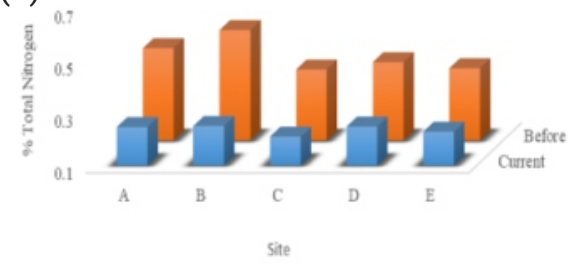

Figure 10. Comparison of total nitrogen studies at 0-20 (a) and 20-40 management

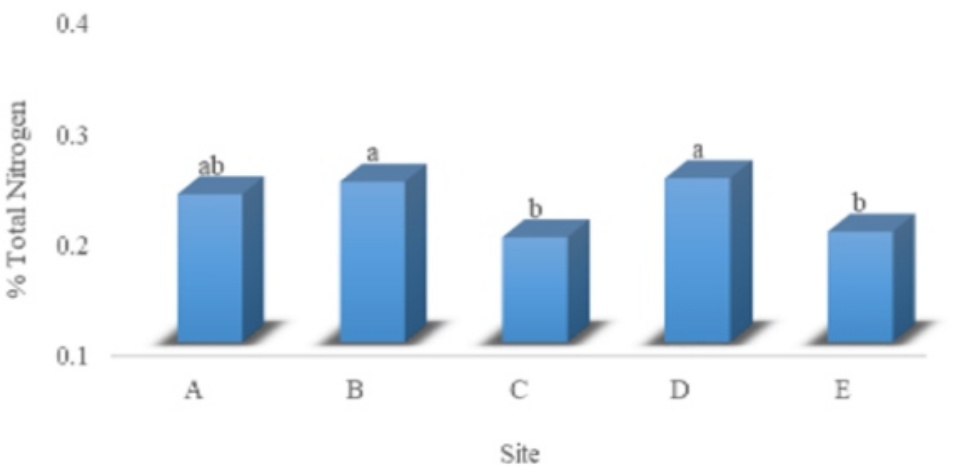

(b)

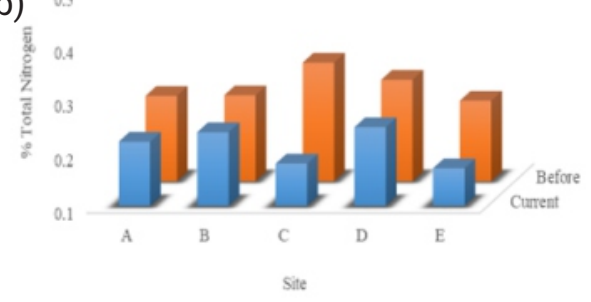

(\%) between the current and previous

(b) $\mathrm{cm}$ depth as influenced by soil

Site

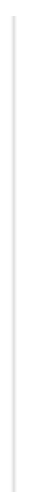

Figure 11. Comparison of soil total nitrogen (\%) between sites at $0-20 \mathrm{~cm}$ as influenced by soil management 


\section{Available Phosphorus}

Soil management influenced the availability of phosphorus in Andisol soil, with an increase in available Phosphorus over a period of ten years in all sites and depths (Fig. 12). However higher available phosphorus was observed in $0-20 \mathrm{~cm}$ depth compared to 20-40 cm depth (Fig. 12). Higher available phosphorus was obtained in sites $A, C$, and $E$ (intensive cultivation) at $0-20 \mathrm{~cm}$ compared to sites $B$ and $D$ (fallowed land) (Fig. 13). This could be attributed to the excessive application of fertilizer rich in nutrient phosphorus (ammonium phosphate). The amounts of available phosphorus obtained in sites A, C, and E (24.96 ppm, $26.64 \mathrm{ppm}$, and 15.80 ppm) were classified as high according to Landon (1991). In sites $B$ and $D(6.95 \mathrm{ppm}$ and $3.20 \mathrm{ppm}$ ) available phosphorus was classified as medium to low (Landon 1991). Continuous application of $P$ fertilizer could have contributed to the higher available $P$ present in the soil. This shows that the type of soil management affects the availability of phosphorus in the soil. Similarly, Comte et al (2012) reported that the total available P differ considerably with land use. Continuously cultivated soil had the highest concentrations of available $\mathrm{P}$ over time. Appropriate application of nutrient $\mathrm{P}$ such as $88-110-60 \mathrm{~kg} / \mathrm{ha} \mathrm{N}-\mathrm{P}_{2} \mathrm{O}-\mathrm{K}_{2} \mathrm{O}$ is important in this type of soil (Tulin et al 2013).
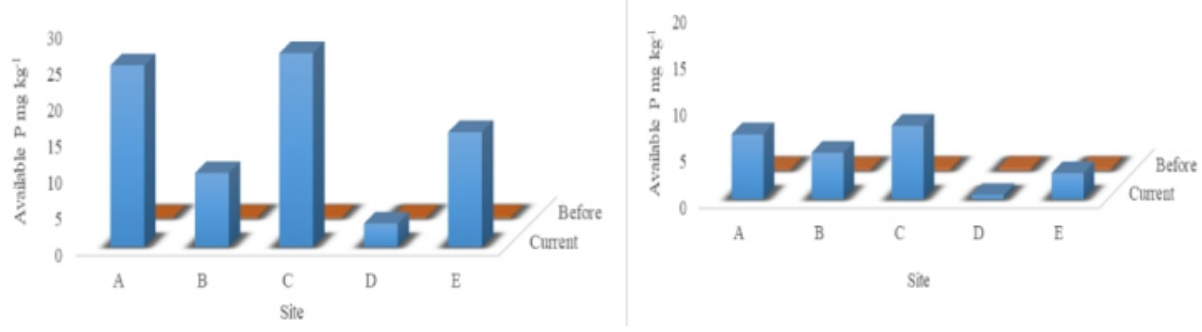

Figure 12. Comparison of available phosphorus $\left(\mathrm{mg} \mathrm{kg}^{-3}\right)$ between the current and previous studies at 0-20 (a) and 20-40 (b) cm depth as influenced by soil management

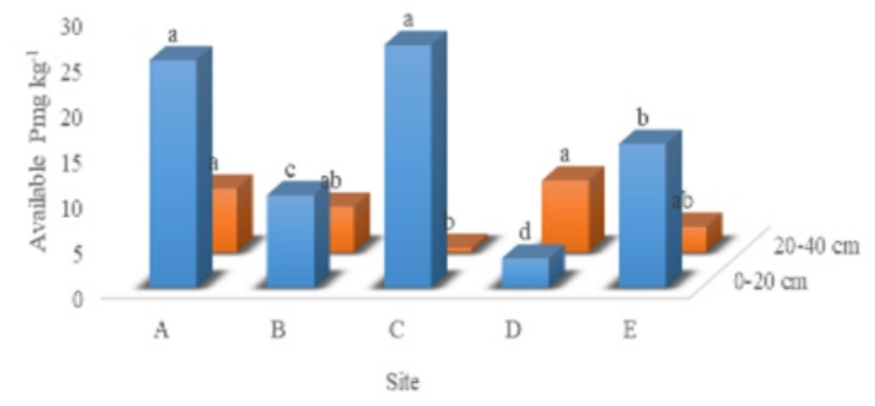

Figure 13. Comparison of available phosphorus $\left(\mathrm{mg} \mathrm{kg}^{-3}\right)$ between sites at $0-20$ and 20-40 cm as influenced by soil management 


\section{Exchangeable Potassium}

Potassium is one of the macronutrients needed for plant growth. Soil deficient in this nutrient cannot sustain the plant to its optimum yield. The results of this study showed that the amount of exchangeable potassium decreased in all sites and depths after ten years (Fig. 14). However, the amount of exchangeable potassium was influenced by the type of soil management. There was a significant difference between sites. In sites A, C, and E (intensive cultivation) (0.124-0.128 ppm), the amount of exchangeable potassium was higher compared to sites $B$ and $D$ (fallowed and) (0.043 and $0.047 \mathrm{ppm}$, respectively) (Fig. 15). This was attributed to the $\mathrm{K}$ fertilizer (muriate of potash) applied to the soil. But all the amounts of exchangeable K obtained was classified as low, which meant that it was $>0.15 \mathrm{ppm}$ (Landon 1991). There is still a need to apply fertilizer rich in potassium in an appropriate amount to obtain higher yield, especially in vegetable production. The management inputs such as fertilizer, herbicides, and irrigation, affect the distinctive physicochemical properties of Andisol, including exchangeable potassium (Rahman et al 2008).

(a)

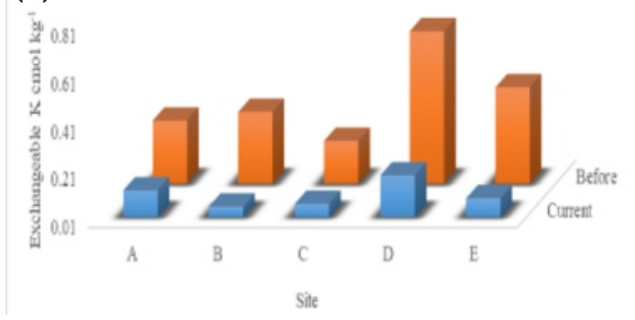

(b)

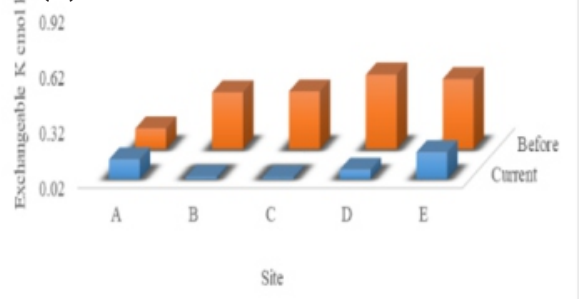

Figure 14. Comparison of exchangeable potassium (me/ $100 \mathrm{~g}$ soil) between the current and previous studies at 0-20 (a) and 20-40 (b) cm depth as influenced by soil management

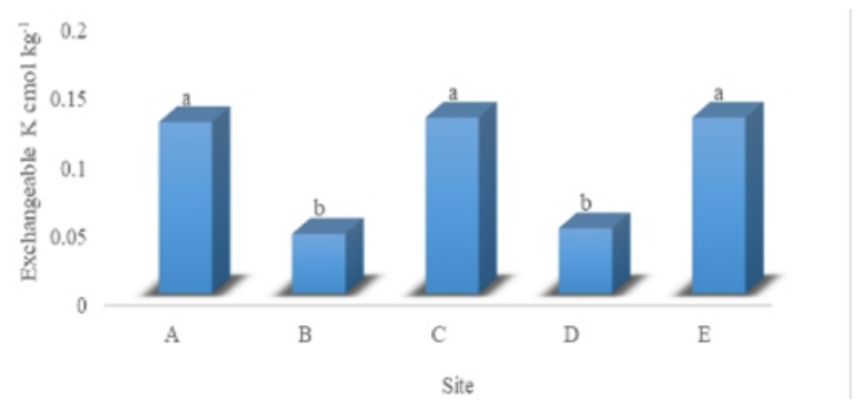

Figure 15. Comparison of exchangeable potassium (me/ $100 \mathrm{~g}$ soil) between sites at $0-20 \mathrm{~cm}$ as influenced by soil management 


\section{Exchangeable Magnesium}

In this study, exchangeable magnesium was affected by soil management after ten years. A significant difference in the amount of exchangeable magnesium was observed in all sites and depths (Fig. 16). The amount of exchangeable magnesium was classified as low to medium (0.03 to $0.41 \mathrm{ppm}$ ) (Landon 1991). This was more suitable for plant growth. The highest exchangeable magnesium was obtained in site $A(0.29 \mathrm{ppm})$ at $0-20 \mathrm{~cm}$ and sites $C$ and $E$ at $20-40 \mathrm{~cm}(0.40$ and $0.41 \mathrm{ppm}$, respectively) (Fig. 17). These sites were continuously used for vegetable production. This could be attributed to management practices like fertilizer application. Exchangeable bases like magnesium were influenced by the type of soil management (Comte et al 2012). Appropriate application of nutrient magnesium can lead to better growth of crops.
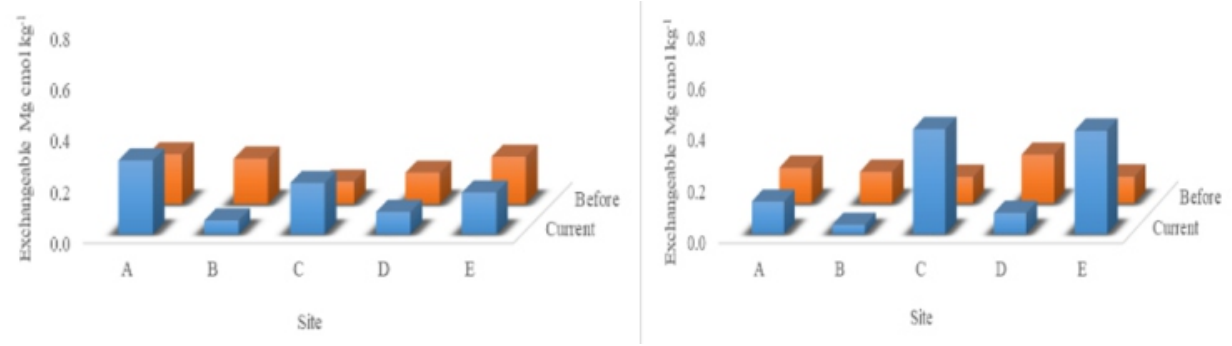

Figure 16. Comparison of exchangeable magnesium (me/100g soil) between the current and previous studies at $0-20 \mathrm{~cm}$ and $20-40 \mathrm{~cm}$ depth as influenced by soil management

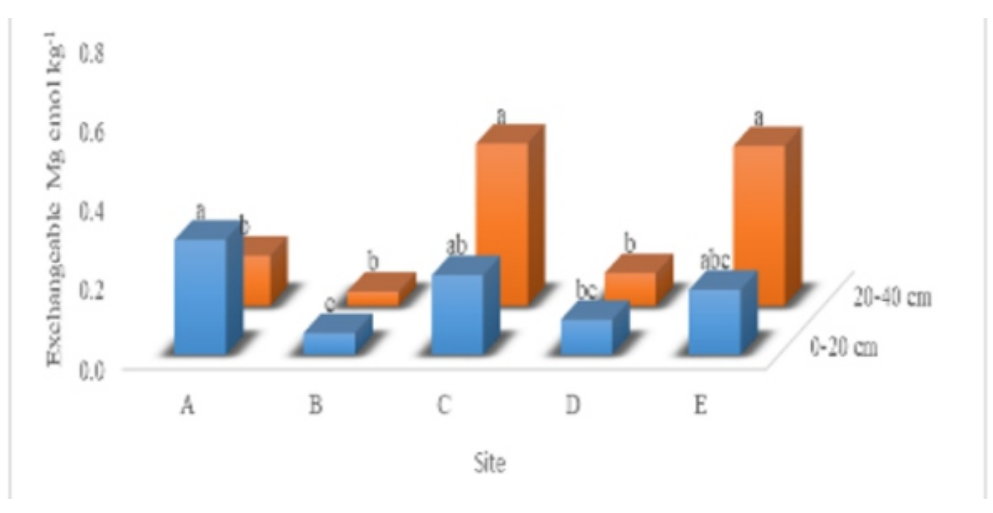

Figure 17. Comparison of exchangeable magnesium (me/100g soil) between sites at 0-20 and $20-40 \mathrm{~cm}$ as influenced by soil management 


\section{Exchangeable Calcium and Sodium}

Exchangeable calcium (Figs. 18) and sodium (Fig. 19) decreased in all sites and depths over a long period (10 years). There was no significant difference in these parameters between sites and depths. All the values for exchangeable calcium and sodium were classified as low ( $<1 \mathrm{ppm}$ ) (Landon 1991). This could be attributed to the type of soil, which was Andisol. Because it is high in allophane and has low soil $\mathrm{pH}$, most nutrients are deficient and are not available for crop production unless appropriate soil management is applied. The longer the time, the higher the weathering process; thus, it was probably leached during the time of the study. According to Halvin et al (1999), in humid subtropical climates, some nutrients are being leached even under natural vegetation. However, agricultural activities can greatly increase leaching losses due to the different soil management practices applied.

(a)

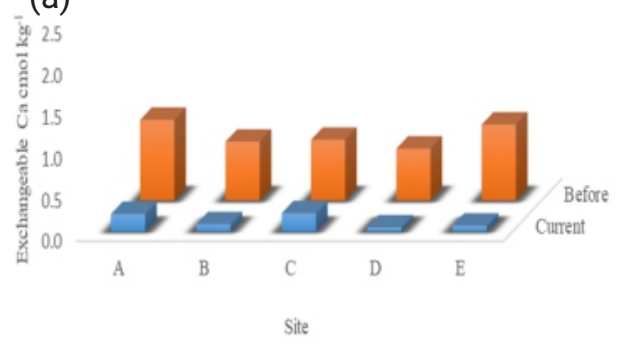

(b)

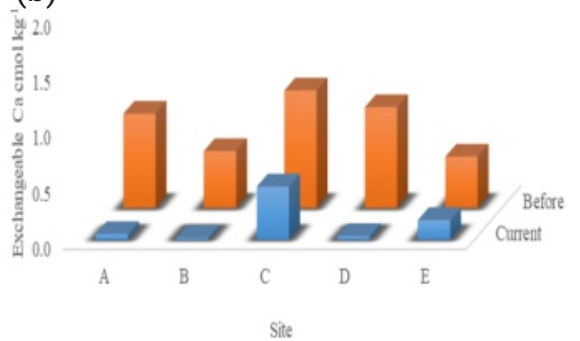

Figure 18. Comparison of exchangeable calcium (me/100g soil) between the current and previous studies at 0-20 (a) and 20-40 (b) cm depth as influenced by soil management
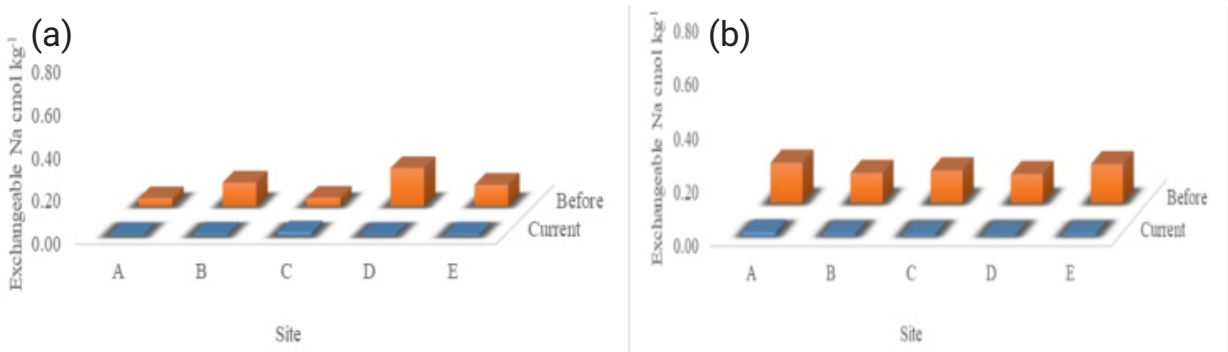

Figure 19. Comparison of exchangeable sodium (me/100g soil) between the current and previous studies at 0-20 (a) and 20-40 (b) cm depth as influenced by soil management

\section{CONCLUSION}

The soil physico-chemical properties of volcanic ash soil or Andisol changed after ten years as influenced by the two types of soil management (intensively cultivated area and fallow area). The impact of intensive vegetable production on soil in Cabintan, Ormoc City, Leyte after ten years were the following: the soil texture remained the same except for the two sites which were intensively cultivated, the bulk density also remained low while the soil pH, soil organic matter, 
nitrogen, and exchangeable bases decreased. However, the available phosphorus increased after ten years of intensive vegetable production. It was also observed that soil moisture content depends on the texture of the soil. The coarser the soil, the lower the moisture content. Knowledge about the changes in the physicochemical properties of the soil (Andisol) over a long period as influenced by intensive cultivation provides valuable information regarding the effects of nutrient inputs on crop productivity. This can, in turn, be used as basis for appropriate soil management practices to enhance and preserve soil quality.

\section{ACKNOWLEDGMENT}

The author is very grateful to the Department of Science, and TechnologyScience Education Institute (DOST-SEI) Accelerated Science and Technology Human Resource Development Program-National Science Consortium (ASTHRDPNSC) for funding this study. Moreover, the author would like to thank Dr. Anabella B. Tulin, Dr. Suzette B. Lina, and Dr. Marlito Jose M. Bande for their technical support.

\section{REFERENCES}

Bahrami A, Emadodin I, Atashi MR, \& Bork HR. 2010. Land-use change and soil degradation: A case study. North of Iran. Agriculture, Biology Journal 1(4):600605

Bhatt M, Singh AP, Singh V, Kala DC, \& Kumar V. 2019. Long-term effect of organic and inorganic fertilizers on soil physico-chemical properties of a silty clay loam soil under rice-wheat cropping system in Tarai region of Uttarakhand. Journal of Pharmacognosy and Phytochemistry. 8 (1):2113-2118

Buol SW, Southard RJ, Graham RC, \& McDaniel PA. 2011. Soil Genesis and Classification (6th ed.). John Wiley \& Sons, Inc.

Climate. 2020 Data.org https://en.climate-data.org/asia/philippines/leyte-1908/

Comte I, Davidson R, Lucotte M, Carvalho C, Oliveira F, Silva B, \& Rousseau G. 2012. Physicochemical properties of soils in the Brazilian Amazon following firetree land preparation and slash-and-burn practices. Agriculture, Ecosystems, and Environments 156:108-115

Diez MCJ, Gallardo AF, Saavedra G, Cea ML, Gianfreda L, \& Alvear MZ. 2006. Effect of Pentachlorophenol on Selected Soil Enzyme Activities in a Chilean Andisol. J.SoilSc.Plant. Nutr. 6(3):40-51

Gong L, Guixiang H, \& Weiguo L. 2016. Long-term cropping effects on agricultural sustainability in Alar Oasis of Xinjizang, China. Sustainability, pp. 8-61

Guadalix ME and Pardo MT. 1994. Effects of liming on soil properties and P solubility in some Spanish Andosols. Geoderma 63 (1):53-61

Havlin JL, Beaton JD, Tisdale SL \& Nelson WL. 1999. Soil fertility and fertilizer an introduction to nutrient management. Prentice Hall, Upper Saddle River, NJ

Hillel D. 1992. Out of the Earth: Civilization and the life of the soil. Berkeley, CA: University of California Press

Igwe CA, Akamigbo FOR, \& Mbagwu JSC. 1995. Physical properties of soils of southeastern Nigeria and the role of some aggregating agents in their stability. Soil Science, 160:431-441 
International Soil Reference and Information Center (ISRIC). 1995. Procedures for soil analysis (L.P. Van Reuwijk, Editor). Wageningen, the Netherlands. pp. 106

International Soil Reference and Information Center (ISRIC). 2002. Procedures for soil analysis (L.P. Van Reuwijk, Editor). Wageningen, the Netherlands. Technical Paper No. 9

Jahn R. and Asio VB. 1998. Soils of the Tropical Forest of Leyte, Philippines I: Weathering, characteristics, classification, and site qualities. In: Soils of Tropical Forest Ecosystems. (A. Schulte and D. Ruhiyat, eds.), Springer-Verlag, Berlin, Heidelberg, New York, pp. 29-36

Jaiyeoba IA. 2003. Changes in Soil Properties due to Continuous Cultivation in Nigerian Semiarid Savannah. Soil and Tillage Research 70:91-98

Johnson SE and Loeppert RH. (2006). Role of Organic Acids in Phosphate Mobilization from Iron Oxide. Soil Science Society of America Journal 70 (1): 222-234

Kangleon RF and Salas FM. 2017. Profile of Copper, Nickel, and Zinc on Three Selected Vegetable Farms at Cabintan, Ormoc City, Philippines. Journal of Nature Studies. $16(1): 18-26$

Landon JR. 1991. Booker Tropical Soil Manual. 2nd ed. Longman Technical and Scientific, Harlow, England

Logan TJ. 2000. Soils and environmental quality. In: Handbook of Soil Science (M.E. Sumner, ed.). CRC Press, Boca Raton, pp: G155-G169

Magahud JC and Asio VB. 2009. Nitrate and phosphate leaching from Lake DanaoAndisol treated with manure and chemical fertilizer. Paper presented during the National Scientific Conference of the Philippine Society of Soil Science and Technology (PSSST), 20-23 May 2009, Davao City, Philippines

McDaniel PA, Lowe DJ, Arnalds O, \& Ping CL. 2012. Andisols. In: Huang PM, Li Y \& Summer, ME. (editors) "Handbook of So)il Science. $2^{\text {nd }}$ edition. Vol. 1: Properties and processes". CRC Press (Taylor \& Francis), Boca Raton, FL, pp. 33.29-33.48

Murphy BW. 2014. Soil Organic Matter and Soil Function: Review of Literature and Underlying Data. Department of Environment, Canberra, Australia

Nanganoa TL, Okelle JN, Missi V, Tueche JR, Levai LD, \& Njukeng JN. 2019. Impact of different land-use systems on soil physicochemical properties and macrofauna abundance in the humid tropics of Cameroon. Applied and Environmental Science. pp. 1-9

Navarrete IA, Tsutsuki K, Kondo R, \& Asio VB. 2008. Genesis of soils across a late Quaternary volcanic landscape in the humid tropical island of Leyte, Philippines. Australian Journal of Soil Research 46:403-414

Nierves MCP and Salas FM. 2015. Assessment of soil phosphorus and phosphorus fixing capacity of three vegetable farms at Cabintan, Ormoc City, Leyte. World J. of Agric. Res. 3(2):70-73

Otsuka H, Briones AA, Daquiado NP, \& Evangelio FA. 1988. Characteristics and genesis of volcanic ash soils in the Philippines. Technical Bulletin, Tropical Agriculture Research Center, Japan

Ping CL. 2000. Volcanic Soils. In: Sigurdsson, H., ed.: Encyclopedia of Volcanoes. Academic Press, San Diego. Pp. 1259-1270

Rahman HM, Okubo A, Sugiyama S, \& Mayland HF. 2008. Physical, chemical, and microbiological properties of Andisol as related to land use and tillage practice. Soil and Tillage Research 101: pp. 10-19 
Redel Y, Rubio R, Godoy R, \& Borie F. 2008. Phosphorus fractions and phosphatase activity in an Andisol under different forest ecosystems. Geoderma 145 (3): 216221

Scheffer F and Schachtschabel P. 1992. Lehrbuch der Bodenkunde. (13th ed.). Ferdinand EnkeVerlag, Stuttgart, 491pp

Shoji S, Nanzyo M, \& Dahlgren R. 1993. Volcanic Ash Soils - Genesis, Properties, and Utilization. Elsevier, Amsterdam

Tulin AB, Dorahy C, Eldridge S, Mercado A, Salvani J, Lapoot C, Justo V, Duna L, Gonzaga N, Quinones CM, Rallos R, Ranises M, Bicamon R, \& Galamba M. 2019. Final Report: entitled "Enhancing profitability of selected vegetable value chains in the southern Philippines and Australia" - Component 1 - Integrated soil and crop nutrient management

Tulin AB, Rallos RV, Rañises MB, \& Dorahy C. 2013. Increasing cabbage production through NPK application in Cabintain, Ormoc City, Leyte, Philippines. Annals of Tropical Research 35 (1):118-130

Wada K \& Gunjigake N. 1979. Active aluminum and iron and phosphate adsorption in Ando soils. Soil Science 128 (6): 331-336

Yaalon, DH. 2000. Down to earth: Why soil and soil science matters. Nature, 407, p. 301

Young IM \& Crawford JW. 2004. Interactions and self-organization in the soilmicrobe complex. Science, 304(5677), 1634-1637 